\title{
Atlantis
}

Critical Studies in Gender, Culture \& Social Justice

Études critiques sur le genre, la culture, et la justice

\section{Hostility, Harassment, and Violence: On the Limits of 'Free Speech' for Minority Feminist Scholars}

\section{Robyn Bourgeois}

Volume 41, Number 1, 2020

URI: https://id.erudit.org/iderudit/1074012ar

DOI: https://doi.org/10.7202/1074012ar

See table of contents

Publisher(s)

Mount Saint Vincent University

ISSN

1715-0698 (digital)

Explore this journal

Cite this article

Bourgeois, R. (2020). Hostility, Harassment, and Violence: On the Limits of 'Free Speech' for Minority Feminist Scholars. Atlantis, 41(1), 9-20.

https://doi.org/10.7202/1074012ar
Article abstract

Following the rich tradition of Indigenous and Black feminists and authors, this article makes use of storytelling to explore the limits of freedom of speech in the academy for feminist scholars belonging to socially marginalized groups and, particularly, Indigenous feminist scholars. Through autoethnography, I expose the ways that freedom of speech was been weaponized against me by people with power to silence and suppress my freedom of speech. Moreover, I draw attention to the ways this has been done to me in order to secure the freedom of speech of other dominant and powerful people. This paper concludes with some recommendations about disrupting this violence and better supporting feminist scholars from minority groups.
All Rights Reserved @ Robyn Bourgeois, 2020

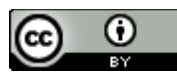

This document is protected by copyright law. Use of the services of Érudit (including reproduction) is subject to its terms and conditions, which can be viewed online.

https://apropos.erudit.org/en/users/policy-on-use/ 


\section{Hostility, Harassment, and Violence: On the Limits of 'Free Speech' for Minority Feminist Scholars}

Robyn Bourgeois is a mixed-race nêhiyaw iskwew (Cree woman) currently residing in Haudenosaunee/ Anishinaabe territory. She is an associate professor in the Centre for Women's and Gender Studies at Brock University where her work focuses on violence against Indigenous women and girls and other forms of gender-based violence.

\begin{abstract}
Following the rich tradition of Indigenous and Black feminists and authors, this article makes use of storytelling to explore the limits of freedom of speech in the academy for feminist scholars belonging to socially marginalized groups and, particularly, Indigenous feminist scholars. Through autoethnography, I expose the ways that freedom of speech was been weaponized against me by people with power to silence and suppress my freedom of speech. Moreover, I draw attention to the ways this has been done to me in order to secure the freedom of speech of other dominant and powerful people. This paper concludes with some recommendations about disrupting this violence and better supporting feminist scholars from minority groups.
\end{abstract}

Keywords: Indigenous feminism, power, privilege, silencing, suppresssion, violence in the academy, weaponizing freedom of speech
Tn the aftermath of one of Canada's deadliest mass shootings by a civilian this past spring, I dared to publicly name this violence as the inevitable outcome of white heteropatriarchy_ and paid the price.

On April 18th and 19th, 2020, a lone white man travelled between rural communities in western Nova Scotia in a replica police car and murdered 22 people before being shot and killed by police during a brief confrontation. As someone who lived for several years in Nova Scotia - or more appropriately, Mi'kmaw'ki, as the local Indigenous peoples refer to this territory - and also as an Indigenous feminist scholar whose career has focused on gender-based violence, I followed the developments of this case intently. While the gendered and racialized aspects of this violence were painfully evident for me, they were largely being ignored in mainstream Canada media; and after many frustrating days of not seeing such analyses included in this coverage, I successfully pitched an article to the scholarly online media site The Conversation, which was published on 24 April, 2020. Titled "Let's call the Nova Scotia mass shooting what it is: white male terrorism," this article drew attention to the regularity with which white males have committed mass murders in Canada and explained this violent propensity as being rooted in whiteness and heteropatriarchy. In line with The Conversation's commitment to the free flow of information, the article was republished on multiple sites and, by the end of April, had been read in excess of 67,000 times. By comparison, the most frequently read The Conversation article from my institution up to that point had been read 33,000 times.

The response from white men was immediate and vicious: within hours of the article being published, I was inundated with emails from angry white men - and I know this because most of them claimed their white masculinity in their responses. Even after I removed the direct contact option through The Conversa- 
tion website, they hunted me down, like the mass murderers I had written about, on email and social media to attack me. They accused me of misandry and racism against white people and dismissed my knowledge, my training, and my ability to conduct research. They claimed I didn't know what I was talking about and mansplained to me why I was wrong in my thinking, never with any meaningful evidence to support these claims. They referred to me as a disgusting human being, both in terms of my ideas and my looks -because, of course, my looks have everything to do with reinforcing heteropatriarchy and nothing to do with my ability to theorize and conduct research. I mentioned my son in the article and was told multiple times that I was an inadequate mother who would scar my son for life. These responses also included threats of violence which scared me so much that I walked my neighborhood with a pocket knife for weeks after publication. While some of these men owned their hate by emailing from their personal email accounts and signing off with their full names, others created anonymous accounts to hide their identity behind their hate.

As if these personal attacks weren't enough, these angry white men reached out to my colleagues and supervisors at Brock University. A white male community researcher documenting acts of terrorism involving Muslim men repeatedly emailed me and many of my colleagues demanding I respond to his Islamaphobic research, which he claimed disputed my arguments about white male terrorism. Some of the men who harassed me indicated that they had emailed my Dean and the President of our university to demand my immediate dismissal. Fortunately, my Dean was entirely supportive and a large contingent of my colleagues signed a letter of support sent to our President. While I am so grateful for this support, it doesn't negate the violence of these attempts to have me fired for voicing my well-founded and well-documented opinion, nor the trauma of being targeted for hostility, harassment, and threats of violence for voicing my perspective on systematic privilege and violence.

Neither does it negate the regularity which I experience attacks for voicing my opinions: as an Indige- nous feminist scholar of mixed-race ancestry (nêhiyaw (Cree) and white settler) living and working in colonial Canada, I have rarely experienced the freedom of speech nor the protection of my freedom of speech enjoyed by other academics, especially those belonging to dominant social groups. Throughout my scholarly career, which has focused on naming, confronting, and disrupting dominant social systems of oppression and their violence, my perspectives are regularly met with hostility, harassment, and violence. I am regularly portrayed as a troublemaker whose knowledge is deemed too emotional, inherently biased, and inferior and, consequently, dismissed. While this suppression has included violence and threats to my employment, it also regularly includes microaggressions directed at undermining my knowledge, my capacity for creating knowledge, and my right to share this knowledge with others. As a result, I rarely experience the level of institutional support directed at protecting my freedom of speech — and specifically my freedom to name, expose, and dismantle power, privilege, and violence-as I did from Brock University in the aftermath of my article in The Conversation.

Using autobiographical storytelling, this current article is organized around ten stories demonstrating lack of freedom of speech I've experienced as an Indigenous feminist scholar in Western colonial academia and beyond. My purpose in telling these stories is to expose the range of tactics used by people with power and privilege to silence and suppress the knowledge of marginalized people, especially when those perspectives challenge this power and privilege. In other words, I demonstrate how freedom of speech is weaponized against scholars from socially marginalized groups in support of systems of social and individual power and privilege. I employ this approach because storytelling is a fundamental component of nêhiyawiwan (Cree culture) and, thus, reflects our ways of knowing and doing. While dismissed as biased within Western colonial knowledge systems that falsely claim objectivity, my nation treats these stories as authentic and important knowledge worthy of consideration. Indeed, this is the same for many other Indigenous nations and storytelling is considered an essential component of Indigenous methodologies and pedagogies (Archibald 2008; Kovatch 2009; Smith 1999). 
Moreover, autobiographical storytelling has frequently been employed by Indigenous (Campbell [1973] 2019; Elliot 2019; Maracle [1973] 2017) and Black (Gay 2014, 2017; hooks 1997; Lorde 1982) women writers in unpacking and articulating their experiences with power, privilege, and violence. While related to our ways of knowing and doing within the Indigenous context, Indigenous women's use of autobiographical storytelling in print, argues Cree/Métis feminist literary scholar Emma LaRocque (1990), has also been shaped by racism, colonialism, and white supremacy. In response to white audiences who "resorted to racist techniques of psychologically labelling and blaming" Indigenous writers for being bitter, emotionally incapacitated, militant, and biased, Canadian publishers have refused to publish anything they considered Indigenous "protest literature" —writing that was perceived as "blustering and bludgeoning [Canadian] society" (LaRocque 1990, xvii). According to LaRocque, "we were directed to tell our 'stories' ... in a manner reminiscent of archival descriptions reflecting earlier colonial attitudes [and not] to be so 'arrogant' or so daring as to analyze or to call on Canadian society for its injustices" (1990, xvii). Thus, from the mid-1970s onward, publishers favoured what they considered "soft-sell Native literature" including personal narratives and autobiographies (LaRocque 1990, xvii), making them an important site where Indigenous and non-Indigenous audiences could access Indigenous women's theorizing around race, gender, and colonialism, albeit within limits established by publishers that curtailed their freedom of speech. For example, in 2018, it was announced that Métis author Maria Campbell's influential 1973 autobiography Half-Breed would be reissued and include an account of the author being sexually assaulted by an RCMP officer at age 14, a story that publishers removed from the text for the publication of the book. Consequently, in addition to exposing dominant social systems of oppression, my purpose in this article is to present a decolonial challenge to Western ways of knowing and doing.

The next section of this paper includes 10 stories, which in addition to describing my experiences with the weaponization of freedom of speech and silencing, contain reflections about the impacts of these experi- ences on me and others, and unpack how these experiences reinforce dominant social systems of oppression within the academy and beyond. This is followed by a discussion and recommendations section where in addition to theorizing what contributed to the institutional support I received after the attacks in April 2020, I suggest some wise practices for supporting minority scholars and disrupting the violence of weaponized freedom of speech. Finally, this paper concludes by considering the importance and power of storytelling.

1.

"You should be grateful for residential schools."

This comment came from a young white man immediately after I had vulnerably shared my family's violent experiences with residential schools and the subsequent effects of intergenerational trauma on our lives in a second-year sociology course focused on race and ethnicity. He then white mansplained to me, despite evidence to the contrary, that residential schools provided Indigenous children with a necessary education that would prepare them for success (and thus, assimilation) in colonial Canadian society and that these schools protected us from tuberculosis and violence.

A white woman student trying to be sympathetic joined the conversation: "I'm sorry about your family's experiences, but it's important to remember that white people never intended for this to be violent. They acted in a way they saw as being in the best interest for Canada and for Native people."

"But also," added another white man, "Why should I be held responsible for something I didn't do? I didn't send Indians to residential school."

Neither the instructor nor other students intervened; instead, more white students joined the discussion to dismiss the colonial violence myself, my family, and all other Indigenous peoples have experienced as a result of residential schools and exonerate themselves from any culpability in this violence. After sitting through an academic debate predominantly conducted by white students on why I, an Indigenous person, was wrong and should be grateful for Indian residential 
schools, I never attended this class again and ended up failing it. Failing this course and jeopardizing my academic future was better than sitting in a classroom of white supremacists exercising their scholarly right to debate my lived reality and reinforce colonial domination.

\section{2.}

I was in the Yukon when I found out. A student I was visiting in Whitehorse told me that a man charged with sexually abusing intoxicated women through his taxi service was transporting the students from my program for Indigenous women leaders. While the university had banned him from being on campus, the on-campus organization I worked for continued to use his company for transportation. In addition to personally transporting our students between the airport and our university before handing off to another driver to bring the students on campus, he was providing in-town transportation, including a discounted limo with champagne service.

Upon hearing this news, I immediately emailed my supervisors, including the white, woman director, my immediate white, woman supervisor within my department, and the white man overseeing finances and travel arrangements for our organization. Leveraging my expertise on violence against Indigenous women and girls, I begged them to prioritize the safety of our students and stop using this accused rapist's services. The white man responded first: "We can't because there's no other option."

Enraged by this outright dismal of Indigenous women's safety, I wrote an impassioned email back and called this white man out: I challenged him as a father of a daughter. I challenged him to think about holding her hand if something like this happened to her. And then I challenged him to think about holding the hand of one of our students who had been sexually assaulted by a predator known to us, making this attack something we could have prevented.

While my immediate supervisor arranged for other transportation for my students, she also scolded me as though I were an impertinent child when I returned: I had been too hard on this white man and he was deeply hurt by my comments. She warned me against being confrontational and suggested I soften my tone. Because clearly, how I confront white people about their complicity in colonial violence and their feelings outweigh the right of Indigenous women to live lives free from violence.

\section{3.}

"Thank you, Robyn. That's enough. I think we get your point."

This is how the white woman director of a community development institute I worked for shut down my attempt to intervene in the university's disturbing decision to co-host Marie Henein, the defense attorney for accused woman abuser Jian Ghomeshi, as a guest speaker, but also the director's equally disturbing attempt to raise this issue in an open staff meeting.

After discovering that Henein, a woman lawyer who not only defends men who are perpetrators of violence but is also infamous for engaging in "whacking"-repeatedly asking purposefully embarrassing questions that draw on highly problematic stereotypes about sexual violence (Rizvic 2018)—was being co-hosted by our university as a featured guest speaker, local feminist scholars, educators, and community members organized to intervene. Our position: providing Henein with a public platform normalized her inappropriate behaviour and traumatized survivors of sexual violence.

Prior to an upcoming staff meeting, our director emailed the women team members of the institute's International Centre for Women's Leadership for guidance, asking if it was appropriate to address the issue of Henein's guest speaking at this meeting. We unanimously agreed that a staff meeting wasn't the appropriate place to discuss this issue and several of us sent individual emails to the director discussing why this was the case. Despite our recommendation, the director decided to raise the issue at this meeting. While acknowledging concerns about hosting Henein, she dismissed them on the basis of freedom of speech and the right of Henein to be heard. Upon observing distress among members of our team, the director put one woman on the spot by asking if she had something to say. Forced to respond, this individual challenged the dir- 
ector's "freedom of speech" position and ended up outing herself as a survivor of sexual violence. Observing this violence against my friend, I intervened: Referencing my own experiences of sexual violence but also my scholarly knowledge of the topic, I attempted to expose the hypocrisy of privileging Henein's freedom of speech over the perspectives of sexual assault survivors, and how this position privileged freedom of speech over preventing further trauma among sexual assault survivors. I challenged her claims that it was possible to have objective and dispassionate debates about sexual violence, especially for survivors, and I challenged her right to force survivors of sexual violence to debate their trauma against Henein's freedom of speech.

In a power move designed to protect the freedom of speech of two privileged women-her's and Henein's - this director interrupted to silence me and foreclose my freedom of speech. She dismissed my experiential and expert knowledge of sexual violence but also the perspectives of other sexual assault survivors in favour of her opinion and freedom of speech with a single sentence: "Thank you, Robyn. That's enough. I think we get your point."

\section{4}

White students, especially white men, regularly challenge my assessment of their assignments for the Indigenous studies courses I teach. They email and/or come to my office and claim that another white person, usually someone close to them with a university degree, has reviewed their assignment and declared it sound. They claim this person knows better than I do and, as a result, I need to review my grading of this assignment. Apparently, as an Indigenous person with lived experience and advanced training and research experience in Indigenous studies, my perspective is inadequate and inferior to this white person. While deeply enraged by this sexist and racist violence, I have to hold my tongue or risk escalating the situation and opening myself to more verbal and potentially physical abuse from these white male students. As someone with expertise in racialized gender-based violence, I know that challenging white supremacy and hegemonic masculinity frequently results in violence and I'm honestly afraid of these white men in these moments. So instead of calling them out for the racism and sexism, I'm polite and try to reiterate my assessments gently. When they don't get the response or grade they believe they should receive, they write racist and/or negative reviews on my course evaluations and ratemyprofessor.com which, in turn, negatively impact my employability and, thus, ability to have my voice included in the academy.

\section{5}

After completing a two-year study and authoring an almost 160-page report on the findings, I was told by the funder that they were unhappy with the report and wouldn't be releasing it. Despite recruiting me on the basis of my training, scholarship, and experience working with socially marginalized communities and directing me to critically explore the ways that oppression operates within the funding organization, they claimed my analyses were unfair and deemed my language "inflammatory." Moreover, despite being a highly qualified researcher with extensive training and experience and having co-developed the research strategy with the funder, they questioned the methodology and challenged the veracity of the findings. Finally, they claimed, because I was an outsider to the organization, I wasn't qualified to make the recommendations I had in advancing their commitment to equity. That report never saw the light of day, and while we jointly own the data and our contract provides me with the ability to publish on the findings, the organization is trying to prevent this from happening through threats of legal challenges.

6

When challenging the right of white settler scholars to use Indigenous ways of knowing and doing responsibly in their curriculum and pedagogical practice, I regularly encounter dismissals of my concerns on the grounds that some other Indigenous person this white person knows agrees with them. For example, after learning that a white colleague teaching Indigenous knowledge systems was using sweat lodges in his pedagogical practice, another Indigenous colleague and I raised concerns about this practice with our institute. Not only did we question the right of this white colleague to use this sacred Indigenous practice as a pedagogical practice with mostly non-Indigenous 
students, we also alerted this colleague and our institute that we were aware that Indigenous Elders across Canada were questioning the appropriateness of using our ceremonies in Western post-secondary institutions. In fact, I had just come from a conference hosted by the Canadian Association of University Teachers where this very topic had been debated among Indigenous attendees.

Our concerns were met with claims from this white instructor that a local Indigenous Elder approved of this practice and, in fact, our opposition was hampering this mutual settler-Indigenous collaboration. As a result, this white person's right to use sweat lodges as pedagogical practice was secured against our concerns about appropriation, colonial racism, and potential harm to participants.

\section{7}

As I prepared to confront management about an unjust and discriminatory workplace, a racialized man who was a colleague pulled me into his office to offer advice. "You're too emotional," he said. "You need to get your emotions under control because they think you're crazy." He advised me that my perspectives would only be valued if I divested them of any feeling. In this moment, he reinforced the Western colonial notion that only objective knowledge devoid of emotion is worthy of consideration and, consequently, dismissed Indigenous ways of knowing and doing that value the gift of emotion. Moreover, he reinforced that patriarchal notion that women are too emotional and, thus, their knowledge is suspect.

I would have been more hurt except this wasn't the first time I've heard this: colleagues_particularly white men and women-regularly dismiss my knowledge because it comes infused with emotion. While this emotion is viewed in Indigenous ways of knowing and doing as a gift from Creator, they view it as a sign of weakness and dysfunction, and a reason to delegitimate and ignore my knowledge. It's awfully hard not to be emotional in the face of colonial racism and heterosexism-to sit in rooms where your very existence and access to basic human rights are debated among mostly white privileged colleagues. It's a position of privilege to not be impacted
- whether physically, mentally, emotionally, or spiritually_by discriminatory hierarchies of power and privilege and get to debate issues dispassionately. It's also a position of privilege and social policing to demand that I respond to these threats sans emotions, denying my pain for the benefit of others. Hiding my pain allows these people to avoid feeling negative emotions related to confronting their own complicity with oppression and violence.

\section{8}

Journal article status: approved with revisions.

Revisions: "this article needs to conform to standard [Western, white, colonial, academic] scholarly reporting practices."

This response not only privileges Western, white, colonial, academic approaches to knowledge production and dissemination over Indigenous ways of knowing and doing, but also forces me to alter and, thus, subvert my authentic scholarly voice. It diminishes my ability to be an Indigenous scholar and employ Indigenous ways of knowing and doing in my research. In other words, it colonizes my scholarship by forcing me to conform to dominant, Western academic standards.

\section{9}

To mark December 6, Canada's National Day of Remembrance and Action of Violence Against Women, in 2018, our Centre for Women's and Gender Studies (WGST) decided to host an event examining violence against racialized people. While not wanting to erase the murders of the 14 white women at Ecole Polytechnique in 1991, whose deaths are the reason we have this day, we sought to expand discussions of this violence to include racialized women and 2SLGBTQQIA (Two-spirit, Lesbian, Gay, Bisexual, Trans, Queer, Questioning, Intersex, and Asexual) people. Consequently, we hosted a panel featuring a Black feminist scholar, a South Asian queer activist, and an Indigenous scholar (me).

After completing our panel, we opened the floor to questions and the first eager hand came from a white woman who is an assistant professor at our university. 
She decried our efforts to bring race to the forefront of this event as undermining the deaths of the 14 white women at Ecole Polytechnique, grounding her perspectives in a relationship with one of these women. She also claimed that after hearing our presentations that she knew less about the experiences of Black and South Asian people and "even less about the experiences of Indigenous peoples." Apparently, we had presented so poorly that we had decreased her understanding of the lived experiences of Black, South Asian, and Indigenous peoples. After one of my co-presenters attempted to challenge her, I took this person to task, indicating that her preference for remembering violence against white women only is part of the problem and amounts to reinforcing white supremacy. While we had patiently listened to her perspective, she refused to listen to ours: I had to remind her multiple times to not disrupt me and listen respectfully to what I had to say. Instead of acknowledging our comments and owning her own complicity in colonial racism, this person loaded up her stuff and walked away. In doing so, she used her white privilege to dismiss our knowledge, foreclose discussion, and avoid taking accountability for the racism we named.

This scene repeated itself a year later. For 2019, we in WGST again wanted to create space for BIPOC (Black, Indigenous, and other people of colour) perspectives, so myself and a Black female author shared the stage. I presented a new paper I was preparing for publication about how the \#MeToo movement had been co-opted by white women in ways that undermine the movement's roots in Black intersectional feminism and, I argued, decolonization and ending sexual violence against Indigenous women and girls. During the question and answer period, a white woman, who had come into my presentation near the end, interrupted and disrupted the discussion about the lack of awareness and response to sexual violence perpetrated against BIPOC people to let us know that as a white woman she had also experienced this dismissal of violence after being raped. Additionally, she referenced a white woman as a founder of the \#MeToo movement. Shocked into silence by having to confront the exact issues I was writing and speaking about, a racialized woman in the audience intervened and challenged this woman for inserting her whiteness into this conversation and, thus, undermining everything I said in my presentation. Again, instead of staying, acknowledging these comments, and owning her complicity in colonial racism, this woman packed up her belongings and exited the room. However, instead of this situation ending there, she took to social media, tagged our event, and publicly declared that she had been discriminated against at this event.

\section{0}

"Do you remember Gorillas in the Mist?" my brother asked me.

Of course, I did: as kids we have watched this 1988 Academy Award nominated film starring Sigourney Weaver as Dian Fossey, the American primatologist who was murdered in her fight to save the mountain gorillas of Rwanda against poachers. I nodded, to which my brother, now choking back tears replied, "I'm so scared that's what's going to happen to you because of the work you do."

And I couldn't reassure him and tell him he was wrong -because the truth is threats of violence and death have always been a normal part of my experience as an Indigenous feminist activist, academic, and author committed to exposing and eliminating dominant social systems of oppression. In a colonial nation state whose existence is predicated on the elimination - whether through assimilation or violence-of Indigenous peoples, my existence and also my efforts to name and dismantle colonial domination and violence pose a significant threat to the colonial order of things in Canada and, as such, are regularly met with innate hostility and threats of violence, especially among white people and, more specifically, white men. In fact, threats of violence have come exclusively from white men. Sometimes these threats occur in person, such as shouted threats of physical and sexual violence by white male bystanders at rallies, but also the more sinister threats whispered in my ear as a white man invades (colonizes) my personal space: "Be careful: Speaking out will lead you to the same fate as your missing and murdered sisters."

These threats have also come via social media and 
email. Sometimes these are anonymous but more commonly, as in the case of the attacks following my article in The Conversation, owned by the author who exposes his name and whiteness. They weaponize their white masculinity against me without fear of consequences because of the privilege and entitlement they experience in our colonial white settler heteropatriarchal society, including their right to abuse Indigenous women with impunity. They demand my silence by threatening acts of violence, mostly directed at me but also my family when I have mentioned them. We have been threatened with rape, physical assault, torture, and death. Several times, I've been threatened with being "disappeared."

\section{Discussion and Recommendations}

The 10 stories I share expose the ways that people, especially those with power and privilege, weaponize freedom of speech against minority scholars. These tactics range from microaggressions to public "calling outs" to physical and sexual violence. While frequently used by people in positions of power, these techniques of power and privilege are accessible to anyone and have been employed against me, albeit infrequently, by other socially marginalized people. This being said, these attacks come most frequently from white people and occur when I'm naming and challenging oppression and violence. While fighting tooth and nail to protect their freedom of speech, their actions work to actively suppress my right to speak and be heard.

The difference in institutional responses between what happened to me this past April and some of the incidents covered in these stories raises some important questions: what made Brock University different? Why was Brock's response one of support instead of suppression of my freedom of speech? While by no means perfect, Brock University has made significant commitments to social justice. Our current strategic plan (2018-2025) prioritizes "fostering a culture of inclusivity, accessibility, reconciliation and decolonization" as one of its four pillars (Brock University 2018, 23-24). This commitment has been met with concrete action including, for example, the creation of the President's Advisory Committee on Human Rights, Equity, and Decolonization (PACHRED), the estab- lishment of a funded and well-staffed Human Rights and Equity Office, and completion of a climate survey meant to explore the diverse experiences of students, staff, and faculty. Brock also has academic commitments to social justice, including its Master of Arts program in Social Justice and Equity Studies, and the Social Justice Research Institute which is home to the scholarly peer-reviewed journal Studies in Social Justice. The university is also home to academic/activist faculty, staff, and students committed to addressing social justice issues, many of whom come from socially marginalized groups. I believe this institutional commitment to equity and social justice - a commitment that is not only stated, but actively pursued-and our community of social justice-oriented people lay at the core of my supportive experience this past April. Notably, while I've experienced support as an Indigenous scholar targeted by racist and sexist attacks, Brock has also actualized its commitment to equity by publicly denouncing white professors who've made racist comments online and in their scholarship. For example, in the summer of 2018, Brock stripped a retired political science professor of his emeritus title after he made racist comments about Indigenous peoples and issued a death threat on social media (Canadian Press 2018); and in June 2020, Brock's provost issued a statement against one of its chemistry professors for a journal article (published and then retracted by the journal) containing misogynist and racist statements (Benner 2020).

At the same time, I can't ignore how power and privilege may have been involved in this response. While my colleagues may have acted genuinely as allies and accomplices, it's always important to consider how power and privilege may operate in any system, as well as critically examining my own privileges and complicity with oppression. While Indigenous, I'm whitepassing and, therefore, benefit from white privilege and don't share the same experiences with racism as many Indigenous and racialized scholars. For example, I have observed how my whiteness along with my overtly happy and friendly personality prevent me, for the most part, from being labelled angry and confrontational-terms commonly used in racist ways to silence racialized, and especially Black, scholars (Williams 2001; Daniel 2019). Brock's strategic commitment to 
decolonization has created a sort of reverence around Indigeneity that offers me privileges and protections as an Indigenous scholar. For example, all of the Indigenous-centred initiatives I've put forward have been wellsupported, both in terms of funding and widespread institutional support. At the same time, as the only tenured female First Nations professor at Brock University, my departure could undermine the university's stated commitment to decolonization. Thus, the University's efforts to make me feel supported and safe can reduce this risk. Again, I want to believe that my colleagues acted as genuine allies and accomplices, but we cannot ignore the ways in which power and privilege may have influenced their supportive response.

Action is critical aspect of nêhiyaw ways of knowing and doing and to assist with this, I want to offer some recommendations on how individuals and institutions can address the weaponization of freedom of speech and the violent silencing of scholars from socially marginalized groups. In addition to drawing on my own experiences, these recommendations arise from years of working with people-educators, scholars, and community members - to address oppression in various contexts, and the many things I've learned from these people and through these processes inform these recommendations.

1. Support Indigenous and other minority scholars who are being attacked and having their freedom of speech denied. This is an important way that Brock University's response differed from my previous experiences: all levels of the university stepped up to support me. In addition to the support of my Dean, 54 of my colleagues signed a letter of support sent to our President defending my freedom of speech and decrying the threats made against me. Many of these individuals also reached out to me individually to check in, offer advice, and reiterate their support. My union president connected me with campus security who not only documented the harassment and threats but also worked with me to create a safety plan me. This support was essential to me surviving and moving forward after these vicious attacks. It bolstered my confidence as an Indigenous scholar and my right to expose and challenge oppression and violence. It also made me feel less alone.
2. Don't be a bystander-intervene when you see someone shutting down an Indigenous scholar or scholars from other minority groups. So many times, people have come to me after to let me know they agreed with me and/or thought how I was treated was wrong. While I appreciate this support and understand the risks involved with intervening, the times that colleagues have stepped forward to publicly support me, including naming and challenging racist and sexist behaviour, have been fundamental to my survival as an Indigenous feminist scholar. In addition to bolstering my spirits in the face of such violence and making me feel less alone, this support has alleviated some of the burden and work required of me to address this violence. While you shouldn't try to speak for or over the individual being targeted, feel free to name the racist, sexist, and other forms of oppression at work and demand an end to violent censures and other acts of silencing. Also make efforts to assist colleagues with understanding how access to freedom of speech is shaped by oppression and how its weaponized as a mechanism for silencing scholars from socially marginalized groups.

3. Address institutional inequity because it's foundational to the silencing of minority scholars. As noted above, Brock University's stated and actualized commitment to addressing equity, human rights, and decolonization played an important role in the support I received when I experienced backlash in April 2020. In pursuing this process, it's essential that people from socially marginalized groups be included at all levels of decision-making, be involved in all processes, and have their voices/perspectives centered.

4. Remember, if scholars from socially marginalized groups are having these experiences so too are students and staff; and its essential that institutions address this kind of violence for everyone.

5. Given the regularity and viciousness of this violence, it's important that institutions have appropriate supports available. In the case of Indigenous scholars, this means having Elder and other culturally safe supports, such as an Indigenous support worker. It's also critical that these supports don't replicate racism, sexism, heterosexism and other forms of oppression. 
This is by no means an exhaustive list; instead, it's a starting point for future discussions of how best to support minority scholars against weaponizations of freedom of speech. This being said, it's important that these discussions centre the perspectives of minority scholars. Borrowing the famous feminist mantra: nothing about us without us.

\section{Conclusion}

"Stories," as Cherokee writer Thomas King proclaimed in his 2003 Massey lecture series, "are a wonderous thing" but "they are dangerous" (9). For once they are told, he explains, stories cannot be called back and remain "loose in the world" (King 2003, 10). While likely to be dismissed as emotional and subjective within Western academia, the stories I've shared are dangerous because they not only speak truth about the limits of freedom of speech for scholars from marginalized social groups, but also expose how, far from being a universal human right accorded to all, freedom of speech as it currently exists in academia but also Western societies operates to secure social and individual power and privilege. Powerful, privileged people fight for freedom of speech insofar as it secures their right to spew hate and, at the same time, actively works to suppress the perspectives of marginalized people, especially when these perspectives challenge this power and privilege. These two strategies, as such, work in tandem to ideologically and materially secure a global elite through the weaponization of freedom of speech aimed at eliminating resistance and, thus, sustaining the dominant interlocking social systems of oppression-heterosexism, racism, colonialism, ableism, and economic exploitation and marginalization-that underpin their power and privilege. By sharing these stories, I expose this truth about freedom of speech.

The stories I've shared are dangerous because they expose some of the tactics by which freedom of speech can be weaponized against scholars from socially marginalized groups. In addition to acts and threats of physical and/or sexual violence which can easily be dismissed as the demented acts of extremists or a few "bad apples," these stories expose the everyday microaggressions - the shushings, scoldings, and claims to superior authority - perpetrated by people who, while not necessarily feeling powerful nor privileged, have nonetheless, used their freedom of speech and/or suppression of speech to silence and suppress me and other marginalized people in the service of power and privilege. In fact, it's my hope that some of you might see your own complicity in such weaponizing of freedom of speech through these stories and strive to do better.

These stories are dangerous because they expose the severity of these attacks for scholars from marginalized social groups. Consider this: as an Indigenous person with white privilege, my whiteness has afforded me certain protections against regular and severe acts of racism inflicted on racialized academics — and yet, it's still this bad. And if it's this bad for me as a white-passing Indigenous feminist scholar, you can only imagine how much worse it is for visibly racialized feminist scholars. At the same time, these stories expose the limits of privilege: our hierarchically ordered global society is intolerant to perceived threats from anyone and, as such, no amount of privilege can protect you from being targeted if you choose to expose and dismantle it. However, if devoted to this work, those of us with privilege have a responsibly to examine and end our complicity in weaponizing freedom of speech against other socially marginalized people-otherwise we are no better than the privileged people who have silenced and suppressed us. In addition to making use of your unique skill sets to better support scholars, faculty, staff, and students belonging to socially marginalized groups, this work must include efforts to dismantle forms of privilege operating within our educational institutions that unfairly target and exclude Indigenous and other minority scholars. This is not a call for privileged people to "rescue" these scholars but, instead, a demand for active dismantling of the educational systems that we have unfairly benefited from at the expense of others.

Finally, these stories are dangerous because they resist these attempts at silencing and, in turn, create the potential for community and collective action against this weaponization of freedom of speech against scholars from socially marginalized groups. For a long time, I kept these stories to myself out of fear that exposing this violence would negatively impact my academic ca- 
reer; and as someone who has only every dreamed about being an academic, has gone into significant debt to fund my education, and as the sole "breadwinner" for my family of five, I've never felt safe telling these stories as long as my employment was at risk. In doing so, I carried the burden of this violence on my own shoulders: instead of holding privileged people accountable, I swallowed this pain out of survival and made myself sick. Moreover, this silence hindered my ability to connect with other marginalized feminist scholars and, thus, mobilize against this violence. Becoming tenured has reduced the threat to my employment and I choose to use this privilege to name and expose this violence and find ways to create community and promote collective resistance among marginalized scholars. For those of you who share these experiences but aren't in a position to tell your own dangerous stories, please know you're not alone. Please know there are lots of us out here who share these experiences and we are here to support you.

\section{References}

Archibald, Jo-Ann. 2008. Indigenous Storywork:

Educating the Heart, Mind, Body, and Spirit.

Vancouver: UBC Press.

Benner, Allan. 2020. "Brock University professor slammed for 'hurtful and alienating' article." The St. Catharines Standard. Last modified 16 June 2020. https://www.stcatharinesstandard.ca/news/niagararegion/2020/06/09/brock-university-professorslammed-for-hurtful-and-alienating-article.html.

Bourgeois, Robyn. 2020. "Let's call the Nova Scotia mass shooting what it is: white male terrorism." The Conversation. Last modified 24 April 2020. https:// theconversation.com/lets-call-the-nova-scotia-massshooting-what-it-is-white-male-terrorism-136938.

Brock University. 2018. Niagara Roots-Global Reach: Strategic Plan 2018-2025. St. Catherines, ON: Brock University.

Campbell, Maria. (1973) 2019. Halfbreed. Toronto: Penguin Random House.

Canadian Press. 2018. "Brock University strips former prof's emeritus status after abhorrent posts." CBC News. Last modified 22 August 2020. https:// www.cbc.ca/news/canada/hamilton/brock-universitystrips-former-prof-s-emeritus-status-after-abhorrentposts-1.4794293.

Daniel, Beverly-Jean. 2019. “Teaching while black: racial dynamics, evaluations and the role of White females in the Canadian academy in carrying the racism torch." Race, Ethnicity and Education 21, no. 1: 21-37.

Elliot, Alicia. 2019. A Mind Spread Out on the Ground. Toronto: Doubleday.

Gay, Roxane. 2014. Bad Feminist: Essays. New York: Harper Perennial.

Gay, Roxanne. 2017. Hunger: A Memoir of (My) Body. New York: Harper Perennial. 
hooks, bell. 1997. Bone Black: Memories of Girlhood.

New York: Henry Holt \& Co.

King, Thomas. 2003. The Truth About Stories: A Native

Narrative. Toronto: House of Anansi.

Kovatch, Margaret. 2009. Indigenous Methodologies:

Characteristics, Conversations and Contexts. Toronto:

University of Toronto Press.

LaRocque, Emma. 1990. "Preface or Hear are our voices - Who will here?" In Writing the Circle - Native Women of Western Canada. Edited by Jeanne Perrault and Sylvia Vance. Edmonton: NuWest Publishers Ltd, $\mathrm{xv}-\mathrm{xxx}$.

Lorde, Audre. 1982. Zami: A New Spelling of My Name -A Biomythography. New York: Crossing Press.

Maracle, Lee. (1973) 2017. Bobbie Lee Indian Rebel. Toronto: Women's Press.

Rizvic, Seila. 2018. "Why many women can't get justice from sexual assault trials." The Walrus. Last modified 27 March 2020. https://thewalrus.ca/whymany-women-cant-get-justice-from-sexual-assaulttrials/.

Smith, Linda Tuhiwai. 1999. Decolonizing Methodologies: Research and Indigenous Peoples. New York: Zed Books.

Williams, Charmaine C. 2001. "The Angry Black Woman Scholar." Feminist Formations-NWSA Journal 13, no. 2: 87-97. 